\title{
Corrigendum
}

\section{Corrigendum to “On Best Proximity Point Results for Some Type of Mappings"}

\author{
Vahid Parvaneh $\mathbb{D}^{1}{ }^{1}$ Mohammad Reza Haddadi, ${ }^{2}$ and Hassen Aydi $\mathbb{D}^{3,4}$ \\ ${ }^{1}$ Department of Mathematics, Gilan-E-Gharb Branch, Islamic Azad University, Gilan-E-Gharb, Iran \\ ${ }^{2}$ Department of Mathematics, Ayatollah Boroujerdi University, Boroujerd, Iran \\ ${ }^{3}$ Université de Sousse, Institut Supérieur d'Informatique et des Techniques de Communication, H. Sousse 4000, Tunisia \\ ${ }^{4}$ China Medical University Hospital, China Medical University, Taichung 40402, Taiwan
}

Correspondence should be addressed to Hassen Aydi; hassen.aydi@isima.rnu.tn

Received 12 January 2021; Accepted 12 January 2021; Published 28 January 2021

Copyright ( 2021 Vahid Parvaneh et al. This is an open access article distributed under the Creative Commons Attribution License, which permits unrestricted use, distribution, and reproduction in any medium, provided the original work is properly cited.

In the article titled "On Best Proximity Point Results for Some Type of Mappings" [1], author "Vahid Parvaneh" was affiliated to "Nonlinear Analysis Research Group, Ton Duc Thang University, Ho Chi Minh City, Vietnam" and "Faculty of Mathematics and Statistics, Ton Duc Thang University, Ho Chi Minh City, Vietnam" which is incorrect. The correct affiliations for this author are

"Department of Mathematics, Gilan-E-Gharb Branch, Islamic Azad University, Gilan-E-Gharb, Iran."

The corrected list of affiliations is shown in the author information above.

\section{References}

[1] V. Parvaneh, M. R. Haddadi, and H. Aydi, "On Best Proximity Point Results for Some Type of Mappings," Journal of Function Spaces, vol. 2020, Article ID 6298138, 6 pages, 2020. 